Canadian University Music Review

Revue de musique des universités canadiennes

\title{
Music in Edmonton, 1880-1905
}

\section{Wesley Berg}

Numéro 7, 1986

URI : https://id.erudit.org/iderudit/1014091ar

DOI : https://doi.org/10.7202/1014091ar

Aller au sommaire du numéro

\section{Éditeur(s)}

Canadian University Music Society / Société de musique des universités

canadiennes

\section{ISSN}

0710-0353 (imprimé)

2291-2436 (numérique)

Découvrir la revue

\section{Citer cet article}

Berg, W. (1986). Music in Edmonton, 1880-1905. Canadian University Music Review / Revue de musique des universités canadiennes, (7), 141-170.

https://doi.org/10.7202/1014091ar

All Rights Reserved (C Canadian University Music Society / Société de musique des universités canadiennes, 1986
Ce document est protégé par la loi sur le droit d'auteur. L’utilisation des services d'Érudit (y compris la reproduction) est assujettie à sa politique d'utilisation que vous pouvez consulter en ligne.

https://apropos.erudit.org/fr/usagers/politique-dutilisation/ 


\title{
MUSIC IN EDMONTON, 1880-1905
}

\author{
Wesley Berg
}

Helmut Kallmann has suggested that the main impression created by a study of musical beginnings in western Canada is that of "amazing speed and variety of development" (Kallmann 1960: 170). Kallmann's account deals chiefly with Victoria, Vancouver, Regina, and Winnipeg, but it will become apparent that most of the factors responsible for this rapid growth were also at work in Edmonton. The presence of well-educated settlers, including many women who had learned to play the piano, the associated need to compensate for the hardships and cultural privation of pioneer life, and the influence of geographical isolation help to explain why musical establishments were, according to Kallmann, so quick to grow in western cities. It will also become clear that the presence of one energetic and talented person was often sufficient to act as a nucleus and catalyst for musical activities once the basic requirements for such activities were present. In addition, Edmonton's early years show how institutions of various kinds can be important in bringing such persons to a community and in providing continuity in times of transition.

\section{Historical background}

Edmonton House was first established on the banks of the North Saskatchewan River in 1795 as part of the rivalry between the North West Company and the Hudson's Bay Company. The two companies were amalgamated in 1821 and under the guidance of John Rowand, Edmonton House quickly became one of the most important furtrading posts in the Northwest, the depot for expeditions to the Pacific and to the Mackenzie (MacGregor [1967] 1975: 36).

In spite of its importance, it was small. When Paul Kane, the artist whose journal and paintings give us such a vivid record of life on the 
prairies and west coast in the middle of the nineteenth century, visited Edmonton House in 1847, there were 130 people living in the fur-trading post (Kane [1859] 1925: 92-93). These were mainly Hudson's Bay Company employees engaged in the fur trade, their wives, almost without exception native women, and a few others who made their living hunting, farming, cutting firewood and freighting for the Company.

By 1880 the population had grown very little: the Edmonton area now had a population of 275 (Edmonton Bulletin 27 December, 1880: 1). In other ways, however, there had been very significant changes. When Paul Kane had passed down the North Sasktachewan with the Hudson's Bay Company flotilla he saw thousands of buffalo. When John McDougall came to the Edmonton area in 1862 with his father, the Rev. George McDougall, there were still countless thousands of buffalo, and one of his main occupations in the winter was either hunting buffalo or trading with the Cree or Blackfoot Indians for buffalo meat to keep their missions at Victoria and Pigeon Lake supplied with food (McDougall [1903] 1983). By 1880 the buffalo were gone, the Indians, former lords of the Plains, were starving, and a transcontinental railroad was about to open the prairies to large numbers of settlers. Life in the Northwest Territories was changing very rapidly; in 25 years provinces and cities would exist where buffalo had grazed and Indians had camped. In that same time, musical life on the prairies grew from the simple customs associated with relaxation around the campfire and entertainment at Christmas dances to elaborate productions by amateur operatic and choral societies presented alongside a constant succession of musical and theatrical events organized by touring professional companies. This cultural growth is documented in the Edmonton Bulletin, which was inaugurated in December 1880 by Frank Oliver who later became a Member of Parliament for the Territories. He proudly called his new publication the smallest newspaper in the world - four pages, five inches wide by six inches deep - and it is from this time on that one 
can get a coherent, continuous account of life in early Edmonton. (MacGregor 1963: 140).

The churches, of course, were one of the main centres of musical activity in any frontier town. They provided an audience, a tradition of music-making that could survive the setbacks that a small group of pioneers would inevitably encounter, and a repertoire that, while usually not very sophisticated to begin with, had the potential to encompass more substantial music very easily. They also provided invaluable leadership in the persons of well-educated pastors who, if not trained in music, at least were usually aware of the value and potential of music in the church, or had wives who were musical. Churches also attracted choirmasters and organists whose contributions often extended well beyond the walls of the particular church employing them. And then, as now, churches provided concert spaces in communities not sufficiently developed to build separate concert facilities.

\section{0-85}

It is always tempting to emphasize the quaint and charming aspects of pioneer life, but it would be wrong to assume that what strikes us as being quaint and unsophisticated implies inferiority of any kind. It is true that most Edmonton residents probably had not heard Wagner's music, although they might have known his name - his death was announced in the Bulletin in March 1883 - but it is not true that they were uninterested in cultural matters. It was simply a matter of degree, of experience and opportunity, and of population. Most of the inhabitants of Edmonton in 1882 came from elsewhere, either Ontario or the British Isles, so it is likely that they had been exposed to music and literature in their youth, and they did their best to preserve and cultivate these interests in the North West. It is important to remember that these were the days when Edgar Dewdney, the Indian agent of the federal government, was starving the Indians into submission, thereby creating despair and rebelliousness 
in the native population and resentment and fear in the European residents; these were the days when almost every issue of the Bulletin reported on an outbreak of smallbox or scarlet fever somewhere in the Territories, or listed the names of children who had died of diphtheria; these were the days when John A. McDougall, trader, or John McDougall, missionary, thought nothing of running 50 miles behind a dog sled, sleeping in an open camp in minus 40 degree temperatures, then rising at $3 \mathrm{a} . \mathrm{m}$. and running another 50 miles the next day. These were the days when survival was a full-time job, when physical strength and stamina most people would now find incomprehensible were the norm, and yet, as John McDougall suggests in the quotation below, musical, literary, and dramatic activities were begun as soon as possible, and were regarded as essential to the health of society on the frontier.

yet the Sabbath services and week-night entertainments of the winter of 1872-73 would do credit to many a larger place. Indeed, had these hardy pioneers not strained to keep up in those things which appeal to the mental and spiritual, there would have been a terrible lapsing into barbarism. Lectures and literary entertainments and concerts, as also a growing interest in church work, kept these men and women shoulder to shoulder with the best in any country.

(McDougall, [1903] 1983: 301)

Around 1880, keyboard instruments were introduced to the community at a fairly rapid rate. In 1879, Ontario-born John A. McDougall and his new bride Louisa found room for an organ in the ox-cart which he brought west. The arrival of two pianos in Prince Albert on the steamer Northcote was still worth mentioning in Edmonton in $\mathbf{1 8 8 3}$ (Bulletin 14 July, 1883: 4). An organ fund was invariably one of the first projects of a new church, and many of the fund-raising activities of the church and its choirs were devoted to this cause. By 1883 the Bulletin announced proudly that "the district is getting well fixed for music. Three pianos have been imported this summer, and the four churches in town are each supplied with an organ, three of which were purchased this summer" ( 3 November, 1883). The organ in the 
Presbyterian Church, for example, had been made by W. Bell \& Co. in Guelph, Ontario, and purchased for $\$ 460$.

The other main source of musical activity in Edmonton in the 1880s was the social gathering, at which music almost invariably played an important part. In such a small community, the church often provided an occasion for a social; such was the case in November 1881 when the ladies of the Presbyterian Church organized an evening of entertainment in honour of their new pastor, Rev. A.B. Baird. The event took place in McDougall Hall, with solos and duets sung by Mrs. John A. McDougall, G.A. Blake, conductor of the Presbyterian Church choir in addition to being the local auctioneer and later a dealer in farm implements, and W. Stiff, former soldier, fiddler, and now real estate agent, accountant and conveyancer. Mrs. McDougall also played the organ, performing such songs as "Roses under the Snow", "Scotland Yet", and "Annie Laurie". When Mr. Petrie rose to sing "Duncan Grey", however, the Bulletin reporter sniffed:

That such a piece was permitted to be sung in such a place on such an occasion, reflects little credit on either the management, the performers, or the audience. It was derisively encored, and was followed by "Green grow the rushes, O". By request, Mr. Blake gave "Ye Banks and Braes", and also by request Sgt. Geldert gave "The British Isles" and as an encore "I wish I was a Fish". ..."Auld Lang Syne" was then sung by the company, followed by "God Save the Queen", and the first social in Edmonton was ended. Taken altogether it was a decided success.

(Bulletin 26 November 1881: 1)

That was about as ambitious as it was possible to be in the isolated hamlet in the early $1880 \mathrm{~s}$. There were no concert, operatic, or choral societies, and no touring professional musicians. What entertainment there was depended on the talents and energies of the residents themselves. Louisa McDougall was typical of a very influential element in the bringing of European civilization to the hard, rough life of the prairies: the white woman, accustomed to the niceties of civilized life in Ontario or England, insisting that her piano or organ 
accompany her into the wilderness (McCook 1954). For a number of years, Mrs. McDougall, initially one of four white women in Edmonton, was an indispensable part of musical events in Edmonton, both as a pianist or organist and occasionally as a singer.

It is difficult to tell how good the playing and singing was - there cannot have been much time for practising, and hard physical labour ws normal for almost everyone - but it is quite clear what kind of music was performed. For many years folk songs and popular songs from the British Isles, especially Scotland, were most often sung. Both John and Louisa McDougall were born in Ontario, but their name betrays their ethnic roots, G.A. Blake had come to Edmonton from England in 1879, and W. Stiff was probably a retired British soldier. Edmonton's prominent citizens tended to be Anglo-Saxons from Ontario or Great Britain, British-Canadians determined to establish British cultural and political insititutions on the prairies (Friesen 1984: 273, 342). It is not surprising, therefore, that at least until 1900 one of the most important social and musical events of Edmonton's year was St. Andrew's night. A report of a concert in the Bulletin of 22 December 1883 is typical; after stating that a selection of national airs had been played on the organ by Louisa McDougall, its readers learned that "Mrs. Lauder gave 'The Dear Little Shamrock' and was rapturously encored, when she gave 'Comin Through the Rye".

Although the activities of the expatriates from Great Britain received the most publicity, it should be noted that Indians also took part in the musical life of the small community. Many of the men were married to native women, and the main purpose of the Fort was to trade with the Indians. Many of the dances therefore were attended by native dancers, and services at Father Lacombe's church in St. Albert were usually in French, English, and Cree. Until 1885 the Fort was also constantly surrounded by the camps of Indians who had come to trade. The European traders were usually outnumbered by their native customers, and the sound of Cree or Blackfoot drummers was a constant element in the Fort Edmonton soundscape. 
Other musical events that were regularly announced and reviewed in the Bulletin during the first five years of the decade were Sunday school concerts, minstrel shows with local performers, organ fund concerts, and many dances and balls. These were great attractions, with the music usually provided by two violins. Laurence Garneau, one of the first, and certainly the most prominent, Metis settlers in the area, was frequently one of the fiddlers, and he was often joined by Joe Flynn, who played the tin whistle. The dancing, consisting of clog dances, Red River jigs and other jigs, reels and cotillions, usually began at six in the evening and continued until four or five the next morning. A common concern of these frontier dances is expressed in the following description of a Masonic Ball that took place on Christmas Day in 1881:

Not the least remarkable ... was the number of ladies - sixteen - the largest number that had been got together at any affair of this kind in Edmonton within the memory of men, or of which there is any authentic record. As our fashion editor is away, we are unable to speak critically of the toilets of the ladies or the costumes of the gentlemen.

(Bulletin 31 December 1881: 3)

The most noteworthy characteristic of both performers and reporters in these early pioneer days is their complete lack of pretension. Everyone with the ability or desire to perform seems to have been accommodated, and disasters were almost invariably treated with kindness and discretion by the reviewers. Audiences were usually enthusiastic. Printed programs rarely gave the true picture of a concert, for many performances were encored, always enthusiastically and sometimes rapturously.

To be sure, the audiences did occasionally have to be reminded of their musical manners. In a review of an Anglican Church organ fund concert held in the Presbyterian Church, the Bulletin reporter had this to say: 
It might not be out of place to hint, however, that the keeping of time by the stamping of feet of a portion of the audience to the tune of The Girl I Left Behind Me, which formed a part of the [instrumental trio] medley, was not, considering the place and occasion, entirely appropriate.

(Bulletin 2 February 1884: 3)

In October 1882 these hardy frontiersmen took time to establish the Edmonton Literary Club. By November 30 members had arranged to have a reading room stocked with newspapers from Winnipeg, Montreal and London, along with journals like Scientific American and the Princeton Review. The Society sponsored debates and often music performed by its members was an important part of their meetings.

The activities of the Literary Society during the spring of 1885 , the time of the Riel Rebellion, are particularly interesting. Though the uprising was on everyone's mind, the Society continued to meet regularly, with the topic for debate for the first week of April being the following resolution: "Resolved that the works of nature are more beautiful to contemplate than the works of art" (Bulletin 4 April 1885: 1). After being entertained by a trio of musicians comprising $W$. Stiff, violin, J.R. Michall, flute, and H. White, tambourine, the company heard the debate and decided for the affirmative.

By the next week the rumours of war were sufficiently strong that a local militia was formed under Captain W. Stiff, the fiddler, and the Bulletin of 11 April 1885 announced that there would be "no meeting of the literary society on Thursday evening" A period of near-panic ensued as the threat of an Indian attack grew more ominous, but Edmonton was spared, and by the fall of 1885 the Edmonton Literary Society had re-organized and was once more meeting regularly (Bulletin 28 November 1885: 1). 


\section{$1886-90$}

The events of 1885 marked a significant turning point in the history of Edmonton. The Indians of the prairies were now impoverished and settled on reserves, and though Colin Fraser's arrival with a load of furs from the Fort Chipewyan area was announced in the Bulletin every spring for years to come, the reason for Edmonton's existence had been irrevocably altered. Now Edmonton turned its attention to attracting and providing for the thousands of settlers that the new transcontinental railroad began to bring to the prairies. The population slowly began to grow and each cart bearing settlers might also contain a musical instrument, or someone who could play. In 1887 the population of Edmonton was 350, according to McGregor (1975: 327). Mrs. McDougall was no longer the only pianist; Mrs. Johnstone-Walker, having arrived with her husband in 1885, was now available for concerts as well. Captain Stiff had returned to playing the fiddle, and had been joined by Dr. McInnis, who played the flute.

Although the population had grown only slightly since the beginning of the decade, musical life in the town of Edmonton began to develop very rapidly. In the fall of 1887 , for example, a glee club was formed under the leadership of Dr. McInnis, flautist, and organist and choirmaster of the Methodist Church. By February of 1888 the glee club was able to give a concert to an audience of 200 people, described by the Bulletin as "the most largely attended event of its kind ever in Edmonton" (Bulletin 25 February 1888: 3). The program consisted of a musical farce, Les deux Aveugles, by Offenbach, and a number of operatic choruses: "The Huntsman's Chorus" from Der Freischütz, "The Soldier's Chorus" from Faust, the "Anvil Chorus", and others, constituting a quantum jump in sophistication from the hearty folksong concerts of the previous half decade.

Other manifestations of a more complex musical society started to appear in 1888. Miss Bessie Philips began to hold music classes in a building on Main Street, and also began to appear as a pianist in concerts. There is further evidence of a growing population of pianists and pianos in the increasingly frequent visits to Edmonton by 
piano tuners, who would announce their arrival one or two weeks in advance in the Bulletin. The community became less isolated as professional entertainers began to make occasional appearances. In April 1888, for example, the presence of Mr. Simcoe Lee, who was scheduled to perform in Fort Saskatchewan and Regina as well, was announced in this way: "Mr. Simcoe Lee, assisted by several distinguished local amateurs, will give an entertainment of Music, Mirth, and Sentiment" (Bulletin 28 April 1888: 1). Such visits were the exception - to reach Edmonton from the main line at Calgary meant a gruelling five-day trip by stage coach - and Edmontonians continued to rely on their own efforts and talents for several more years.

\section{1-1899}

Finally, after nearly a decade of disappointment and frustration at seeing the transcontinental railway built along a southern route that bypassed Edmonton, the hamlet was reached by a line from Calgary in the summer of 1891. Not only did this encourage growth, making it possible for Edmonton to be incorporated as a town with a population of 700 in 1892, but it also meant that touring dramatic and vaudeville companies could now come to Edmonton with relative ease.

"The appearance of the first professional theatrical troupe marks an era in the progress of civilization here" (Bulletin 23 May 1892: 1). Thus the arrival of the Caroline Gage theatrical group was announced in the spring of 1892. Several months later the first touring vaudeville company made its appearance (Bulletin 15 August 1892: 1). The Fax Humourous Concert Co. included a character vocalist, an elocutionist, soprano, and pianist among its members, and the emphasis on Irish songs in its program was undoubtedly calculated to please a predominantly Anglo-Saxon audience. Although the town was still too small to attract the steady stream of companies that would be arriving when Edmonton was incorporated as a city with a population of 8,350 in 1904, from now on the citizens of Edmonton 
did not have to rely solely on their own resources for their entertainment.

That is not to say, of course, that they ceased to make music themselves. The Bulletin reported regularly during the 1890 s on church concerts, smoking concerts, minstrel shows, St. Andrew's night concerts, school concerts, and various other "entertainments" featuring local talent. In 1892 the town of 700 people supported two bands, the Edmonton Brass Band and the Edmonton Fire Brigade Band. No fair, skating carnival or other celebration was complete without the presence of one or both of these groups, and their busy schedules were faithfully reported by the newspaper. That same year saw the opening of Edmonton's first concert hall, Robertson's Hall, seating 300 people, which served as the location for many theatrical and musical events until it burned down in 1906.

Individuals with energy and talent could be extremely important in galvanizing a community into musical activity. The railroad had reached Calgary in 1883, and as a result, Calgary's development had been much more rapid than Edmonton's, but it was only when Judge Roland Winter, an amateur cellist, and his wife, an actress, arrived in 1893 that Gilbert and Sulivan works began to be performed regularly. Later, Colonel J.S. Dennis, an enthusiastic amateur musician, played an important part in organizing large-scale musical productions, and was also responsible for persuading Annie Glen Broder to come to Calgary in 1903 (Kennedy, 1952: 6-13). This English-born graduate of the Royal College of Music subsequently became one of the most prominent figures in Calgary's musical establishment. Edmonton, smaller and more isolated, had to wait until the turn of the century before music-making of this kind became possible, but one can find similar examples of leadership in the 1890s as well. In March 1892, for example, A.G. Randall became the organist of the Anglican Church in Edmonton. An Englishman from a musical family - in 1898 his sister Mabel received two bronze medals in musical examinations given in London - he seems to have made his 
living as town clerk and free-lance accountant. In addition to his regular duties at the cathedral, he set about almost immediately to organize more ambitious musical projects. In the fall of 1893 his choir at All Saints' Cathedral began to prepare a cantata, The Rose Maiden, which was performed in March 1894. Later in April the group performing The Rose Maiden became the Edmonton Philharmonic Society, and by July rehearsals had begun for performances of Gilbert and Sullivan's Trial by Jury and Slaughter's operetta, His Only Coat.

No record of a performance of these two works has been found; an appeal at the end of August for more ladies in the society probably indicates the precarious basis on which these early associations were formed. A.G. Randall clearly did not allow such failures to discourage him, however, and in November 1894 a choir he had organized the previous July in the Presbyterian Church gave a sacred concert that included excerpts from Messiah and The Creation. Less than a year later, in September 1895, the same choir performed Farmer's cantata, Christ and His Soldiers, followed by a pastoral, The May Queen, in February 1896. In the 4 May 1896 issue of the Bulletin Randall let it be known that he had procured Rossini's Stabat Mater for production by a special choir, with practices to commence at once. In the meantime he organized a benefit concert that took place in September 1896, and in February 1897 the Glee Concert presented excerpts from Rossini's Stabat Mater, along with some Handel choruses. In January 1898 he helped bring the Apollo Glee Club into existence, serving as conductor, and in November 1898 he would again be instrumental in organizing a dramatic and operatic society, with plans to perform Gilbert and Sullivan's Pirates of Penzance.

In a town as small as Edmonton in the mid 1890s, almost everthing anyone did was news, making it possible to find out details of the 
lives of prominent citizens that would normally not be known. Although the Bulletin is the only source of information about this musician who guided Edmonton's musical development during the

last decade of the nineteenth century, we learn that in early June 1896 A.G. Randall had a heart seizure in church, shortly before he became the father of a son. We learn that when gold rush fever hit Edmonton in the spring of 1897, not even musicians were immune, for the Bulletin reported "A.G. Randall is away securing a few gold claims for himself along the river" (Bulletin 29 April 1897: 1), and by August he was the head of a company planning to outfit prospectors heading for the Yukon. His musical activity continued unabated as he prepared his Presbyterian Church choir for Sunday morning services - the anthem for the day was usually announced in the Bulletin

- and as he organized and conducted the musical portion of the Jubilee celebration of Queen Victoria's reign in May 1897.

Certain key elements of a mature musical life were still missing in 1897 , but it is clear that musical activity could be stimulated relatively easily by a leader like Randall, even though it might not be possible to sustain a group through several seasons. Church choirs were becoming more ambitious in their efforts, bands and orchestras were active, the sons and daughters of the first citizens of Edmonton, people like Alex McCauley and Alice McDougall, had received musical educations and were now appearing as pianists, and all these factors contributed to laying the groundwork for the developments following 1900. Still, when the crunch came, people knew where their priorities lay; here is an advertisement from the Bulletin of 23 March 1899: "I am coming to Edmonton to settle in April and want to sell a good square piano in first-class condition ... or exchange for two cows or cow and calf, or whatever you have useful for farming". 


\section{0-1905}

That was in 1899. Although the frontier was obviously still close at hand, the next five years witnessed a remarkable development in both the quantity and quality of Edmonton's musical life. Already there was nostalgia, as in this description of an Old Timers Ball:

The ball which is held every year under the auspices of the Old Timers Association, in memory of and perhaps to a certain extent a revival of life in the early days when conditions of settlement and civilization were different, when society was scarce and fashion an unknown quantity, when the moccasin did duty as a dancing pump and the buckskin coat was the recognized swallow-tail.

(Bulletin 9 February 1900: 6).

But there was no going back, and one of the most important factors in this development was a very rapid increase in population. In 1901 Edmonton had a population of 2,626 while Strathcona, its rival across the river, numbered 1,550 inhabitants. Three years later, Edmonton had grown to a city of 8,350 ; Strathcona was incorporated as a city in 1907 with a population of 3,500; and by 1908 the residents of the two cities numbered 18,500 and 4,500 respectively (MacGregor [1967] 1975: 327). The implications of these figures for the building of a musical establishment are clear: more potential singers and instrumentalists, more potential students attracting more music teachers, larger audiences, and a larger market for music stores.

Even so, it still usually took one person to act as the energetic nucleus around which musical events could form. A.G. Randall had played the part in the 1890s and now, at the end of January 1900, with Randall preparing to leave for Winnipeg, the man who would be that nucleus for the next few decades made his first appearance. At the farewell concert organized to honour Randall on his departure, a newcomer to Edmonton, Vernon Barford, was hailed as a skilful accompanist and soloist "recalling memories of the brilliant performances of Capt. Holt of Klondike fame" (Bulletin 2 February 1900: 6). 
Vernon Barford was born in Berkshire, England, in 1876 and attended the choir school of Worcester Cathedral from 1887 to 1892 (Kallmann, 1981: s.v. "Barford"). After emigrating to Canada in 1895, he spent one year on a homestead in the Qu-Appelle district of Saskatchewan before giving up farming to teach piano in several nearby towns and to play the organ at the cathedral in Qu- Appelle. Early in 1900 he arrived in Edmonton to become organist and choirmaster at All Saints Church, where he supplemented his salary of $\$ 150$ per year with another $\$ 500$ earned as a private piano teacher. The latter activity alone became an integral and essential part of Edmonton's developing musical culture; by September of 1900 his students performed in the first of more than 100 monthly recitals he organized in the years between 1900 and 1912. The early ones were always announced and sometimes reviewed in the Bulletin, each one with printed programs (some still in the possession of Barford's son, Rev. John Barford of Edmonton), most of them augmented by a guest artist or choir and concluding with a solo by Barford himself.

In addition to his work at the Anglican Church and as a private teacher, he soon became an indispensable part of all musical activities in Edmonton. He was a gifted sight reader and improviser, and there were few smoking concerts, young bachelor's assemblies, or organ fund concerts, whether in the Anglican, Presbyterian or Methodist Churches, at which Barford did not "preside at the piano in his usual splendid manner," to use the words of the Bulletin reporter. He was especially well known for his stirring rendition of "Onward Christian Soldiers". When a touring musician came to Edmonton, Barford was often pressed into service as an accompanist. Besides being a composer and arranger, frequently printing and publishing his own compositions for sale at local music stores, he also took part in dramas and was a gifted athlete who at various times became golf and tennis champion of Edmonton.

Perhaps his most noteworthy achievement in those early years was the founding in November 1903 of the Edmonton Operatic and Dramatic 
Society, leading to the performance in April 1904 of The Chimes of Normandy, a comic opera by Planquette. Already in January 1901 he had been named the conductor of a choral society (Bulletin 11 January 1901: 4), but it took almost three years for the dream to be realized. Edmonton's "first opera" was a huge success. With costumes imported from Chicago, scores from Boston, and an orchestra consisting of piano, organ, a half dozen violins, cornets, cello, clarinets and drums, it played to full houses four nights running at Robertson Hall (Bulletin 11 April 1904: 3). The audience was enthusiastic: Vernon Barford was roundly applauded, of course, and $\mathrm{Mr}$. Day was given an ovation and a rousing rendition of "For He's a Jolly Good Fellow" at the end of the performance. The Society concluded the season with a ball and immediately began to plan for the future. An indication of Edmonton's rapidly growing musical maturity is the fact that in 1905 the society performed Box and Cox and Trial by Jury, followed in 1907 by a lavish production of Pirates of Penzance, the beginning of a series of productions of Gilbert and Sullivan operettas that continued into the next decade.

There were several factors that made this kind of continuity possible. With Edmonton's population increasing rapidly it was more and more likely that there would be others interested in music and able to help with organizing and performing large productions. One such person was Howard Stutchbury, a baritone who came from Calgary in 1903 and immediately plunged into Edmonton's musical world, singing at Vernon Barford's student recitals, St. Andrew's night concerts, church concerts, and playing a leading role in the Operatic and Dramatic Society's productions. He was clearly an energetic and enterprising man, and must have been the perfect match for the equally energetic Barford. In January 1903 he began to advertise for voice students; in March he organized the Strauss Piano Company, which promised to supply Edmonton with high quality, locally made instruments; and in April he starred in The Chimes of Normandy, an eventful schedule for a man who had only arrived in Edmonton in November or December of the previous year. Several years later, in 
1908, he, along with Vernon Barford, W.J. Hendra, Jackson Hanby and Beatrice Crawford, organized the first music festival in Canada.

Individuals like Barford and Stutchbury were essential to the building of a conventional musical establishment; every city can look to a handful of men and women with talent, vision and determination who almost single-handedly brought culture to its citizens. The difficulty, of course, is that cultural enterprises may founder when these individuals move away, or get old and die. This is where institutions become important. They attract teachers and performers who almost inevitably participate in community activities as well, and they provide continuity, hiring new teachers and performers when the original ones leave or retire. The importance of the churches in this matter has already been pointed out - Vernon Barford came to Edmonton because of the Anglican Church - and in July 1903 the Methodist Church initiated a project that was to have far-reaching implications for the development of music in Edmonton.

The project was a college that would offer courses in the arts, business, and music. Initially it was referred to as McDougall Methodist College, then Edmonton College, and in September 1903 as Alberta College, the transformation in name reflecting the sincere desire of the Methodists who had conceived the idea to create an institution free of denominational biases. At first it was announced that Vernon Barford was to be in charge of the music program, but by January 1904 Percy Hook, a pianist late of the Toronto College of Music, became the director of music, with a staff consisting of Beatrice Crawford, piano, Ethel Webster, voice, and Edith Webster, violin. Soon there were faculty and student recitals whose programs for the first time resemble those with which we are now familiar. In a faculty recital in March 1905, for example, Ethel Webster sang arias by Mascagni and Gounod, with her sister playing violin obligato, while Percy Hook began the second half of the program with Beethoven's Sonata, Op. 13, the "Pathetique," following that with a Liszt 
transcription of a Schubert song and Chopin's "Berceuse" and "Ballade in Ab" (Bulletin 25 March 1905: 1).

In addition to representing Alberta College with music of hitherto unknown seriousness, the faculty members were available for musicmaking in the community as well, participating as soloists or ensemble members in various community groups. Only a month after the first production of the Edmonton Operatic and Dramatic Society in April 1904 a choral society was organized with Rev. H.A. Gray, rector of All Saint's Church and frequent soloist and quartet member, presiding. Percy Hook of Alberta College was named conductor and the group began to prepare Gounod's Redemption for a performance of the "first oratorio in Edmonton" in December. The actual performance took place during the first week of December, the first half devoted to choruses and arias from Messiah and Elijah, the second half presenting choruses and arias from the Gounod work. As was usually the case, the production was a community effort, with Vernon Barford acting as accompanist and Howard Stutchbury singing solos, but Alberta College faculty played a very important part in the performance. The Bulletin presented its readers with an explanation of the meaning and significance of oratorio, assuring them that "December 6 will be a red letter day in the history of music in Edmonton."

One other way in which the presence of Alberta College enriched the musical life of the growing Alberta city occurred when students at the college took exams with various eastern institutions. At the end of June 1905, for example, an examiner named Frank Welsman representing the Toronto College of Music arrived, and was immediately persuaded to give a piano recital in the Methodist Church, assisted by Miss Ethel Webster, the local singer. A week later J.D.A. Tripp arrived to conduct examinations for the Toronto Conservatory of $\mathrm{Mu}-$ sic. This distinguished Canadian pianist (Kallmann, 1981: s.v. "Tripp, J.D.A.") was also prevailed upon to give a recital. As was usual in such recitals, it was a mixed program, including some songs by Brahms sung by Helen Kirby Ferguson, a Toronto singer who had 
accompanied him, and selections by the local choir, the concert being in aid of the pipe organ fund.

Thanks to the coming of the railroad, and a rapidly increasing population, Edmonton was now on the touring circuit for a host of soloists and companies of different kinds (Sheremata 1970). One of the most significant visits was that made by Emma Albani, the great French-Canadian soprano, in April 1901. "The old queen of song has come and gone .... April 23rd, 1901 will hereafter be a day to tell the next generation about." Although the reviewer questioned all "the trilling and foreign languages," he went on to say:

but we must bow the head and say she is a great voice and great work of nature. Canada is proud of Albani, and Edmonton, in the far north, is ready to forgive her stage coquetry and her skirt fantasies and her acrobatic performances and the twisting of the right corner of her mouth just for the sake of hearing her sing. The great heart of her voice is there yet.

(Bulletin 26 April 1901: 6)

As in most recitals in 1901, Albani was assisted by a number of artists, including a contralto, baritone, violinist, flautist, and pianist.

The review was written by Augustus Bridle, a local teacher, and organist and choirmaster of the Presbyterian Church since July 1900. Shortly after the concert by Albani, Bridle left Edmonton to take up a "lucrative position in Stratford" (Bulletin 17 May 1901: 1). He eventually became a prominent journalist and promoter of artistic activities in Ontario (Kallmann, 1981: s.v. "Bridle, Augustus").

Not all concerts were as well publicized, or generated as much excitement, as Albani's. On 13 February 1903 a Hungarian violinist, Paul Szigety, stepped off the train from Calgary, unannounced and without the customary press releases. He hired a hall and an accompanist, Vernon Barford, and proceeded to give a concert on the 16th, the program consisting of music by Sarasate, Wienawski, Raff, 
and some "gymnastics" of his own composition. It was poorly attended, and the Bulletin had this to say about the performance:

The playing was entrancing and of a standard that has seldom if ever been heard in the West. It was, however, beyond the understanding of many present and hence beyond their appreciation also.

(Bulletin 16 February 1903: 1)

This comment reveals why a more typical concert by a touring artist might be advertised in this way:

Rosa D'Erina, Prima Donna Soprano and World Renowned Lady Organist, Vocalist and Pianist, by appointment to her Royal Highness the Princess of Wales, assisted by G.R. Vontom, the inimitable Humorist, Raconteur and Tenor Vocalist - one night only at Robertson Hall.

(Bulletin 16 November 1904: 2)

Humour was an indispensable element of a successful concert in a frontier city like Edmonton at the turn of the century. When the Westminster Abbey Choir visited Edmonton on their way to Australia in February 1903, the program contained very little choral music, consisting mostly of solos and small ensembles, with a humorous sketch to conclude: The visit was the highlight of that winter's concert season, and it was with great pride that the citizens of Edmonton welcomed the choir that had just recently sung at the coronation of King Edward VII. The extraordinary significance of the concert can be measured by the fact that all curling matches scheduled for that night were postponed.

There was also hardly a week after 1900 when Edmonton was not being entertained by a dramatic company, vaudeville company, or light opera company. The most common, of course, were the vaudeville companies. Here there were no claims to serious artistic achievement; entertainment came first, as this review from the Bulletin of 17 February 1902 reveals: 
The performance of the Alabama Warblers, at Robertson Hall on Saturday night, was well attended. Prof. McKanlass gave a good exhibition of his skills as a violinist. The programme consisted of coon songs, clog dancing and cake walks, intermixed with the usual jokes and pleasantries.

Sometimes the performances slipped beyond the bounds of what was considered acceptable. In a review entitled "Disgraceful Show," the Maridor Goulding concert was condemned with these words:

Three women and a girl composed the entire cast and for rank coarseness and indecency this show holds the palm .... Their sex was the only thing that saved the party from a very liberal application of hen fruit.

(Bulletin 21 September 1903: 3)

But there was more than vaudeville. The Harold Nelson dramatic company visited Edmonton every year, presenting Shakespeare Hamlet, The Taming of the Shrew, Othello - to full houses, and the Bulletin wrote approvingly of his efforts to raise the standards of theatre in the Territories. The Beggar Prince Opera Co. and the Roscian Comic Opera Co. made regular appearances, presenting works like Auber's Fra Diavolo, Sousa's El Capitain, Planquette's Chimes of Normandy, and many Gilbert and Sullivan works. For a week or two at a time, people in Edmonton could attend a different opera every night. The performances were almost always well attended, frequently being held in the new Thistle Rink, which seated 1500 people.

It is unlikely that any Edmonton residents would have wanted to turn away the touring soloists and opera companies that were now such an important part of their city's cultural life, but their presence does not seem to have affected the energy and time devoted to music-making by local musicians. The geographic isolation mentioned earlier was still a factor even after the coming of the railroad, and the residents of prairie cities continued to depend on self-reliance and ingenuity to meet their musical needs. A striking example of this began with the concert held on 31 August 1905 to celebrate the official inauguration 
of Alberta as a province. Vernon Barford was in charge, as usual, organizing, arranging and conducting a program displaying the best musical talent of the city, with numbers performed by a large mixed choir, male chorus, and several soloists, all accompanied by an orchestra. Sir Wilfred Laurier and Governor General Earl Grey were present, and in his comments Earl Grey remarked on the grace, refinement and distinction of the program, "especially when I reflect upon the fact that it was your own home growth" (Bulletin, 2 September 1905: 8).

No doubt he witnessed a similar celebration in Regina several days later, and it is probably these experiences that led him to proclaim a competition, to be held in Ottawa, to which dramatic and musical companies from all the provinces would be invited. The first Governor General's competition took place in January 1907, with eight musical and eight dramatic companies representing Halifax, St. John's, Montreal, Quebec City, Ottawa, Toronto, Hamilton, Winnipeg, Regina and Victoria.

The absence of an Edmonton company was lamented by the Bulletin as it told its readers of the competition, and assured them that next year this would be corrected (Bulletin 18 January 1907: 2). In April Mr. Bulyea, the Lieutenant Governor of Alberta, received a letter from Lord Grey informing him that the first competition had been so successful that another one was being planned. Bulyea wrote to Howard Stutchbury asking about the possibility of forming a company to represent Edmonton in Ottawa (Bulletin 2 April 1907: 7), but instead of sending a small group of people to a distant city at great expense, Stutchbury, Barford, Hendra and Hanby decided to have their own festival in Edmonton. The first regional competition festival in Canada was thus established, not "in response to the wish of the governor-general, Earl Grey, to see provincial festivals established in Canada" (Kallmann, 1981: s.v. “Alberta Music Festival Association"), but as a typically innovative response to conditions imposed by the isolation of the prairies. The festival, held May 4-5, 
1908, was a great success, with competitors coming from as far away as Cardston in southern Alberta on special trains at half fare just for the occasion. The festival drew more than 100 entries (Bulletin 26 April 1908: 10), considerably more than the numbers given in the articles in the Encyclopedia of Music in Canada ("Alberta Music Festival Association" and "Competition Festivals"). Like the concert of 1905, the final concert was a gala community affair, with the trophy winners and a mixed chorus of 200 singers, a male chorus of 100 voices, and an orchestra of 40 , all conducted by Vernon Barford, performing for an audience of 2000 .

Although the Alberta Music Festival of May 1908 clearly had its roots in the inaugural concert of 31 August 1905, the discussion of its beginnings has led beyond the temporal limits originally proposed for this essay. It is, however, so characteristic of the way in which musical life developed in Edmonton during its early years, and so obviously a culmination of the previous twenty-five years of development, that its inclusion seemed not only appropriate but necessary. The festival marks a stage in the development of music in Edmonton that was once more made possible by dedicated, unselfish leadership on the part of a few people, supported by a community willing to work hard at making music, a community for whom music filled strong spiritual, intellectual, and social needs.

\section{REFERENCES}

1880-1908: Edmonton Bulletin.

FRIESEN, GERALD

1984: The Canadian Prairies: A History. Toronto: University of Toronto Press.

KALLMANN, HELMUT

1960: A History of Music in Canada. Toronto: University of Toronto Press. 
KALLMANN, HELMUT et al. eds.

1981: Encyclopedia of Music in Canada. Toronto: University of Toronto Press.

KANE, PAUL

1925: Wanderings of an Artist Among the Indians of North America. Masterworks of Canadian Authors. [1859] vol.7. Toronto: The Radisson Society of Canada.

KENNEDY, NORMAN J.

1952: "The Growth and Development of Music in Calgary (1875- 1920)". M.A. Thesis, University of Alberta.

McCOOK, JAMES

1954: "Pioneers Preferred Pianos," The Beaver, 284 (Winter, 9-11.

McDOUGALL, JOHN

1983: In the Days of the Red River Rebellion. [1903] Reprint, with introduction by Susan Jackel. Edmonton: The University of Alberta Press.

MacGREGOR, JAMES G.

1975: Edmonton: A History. [1967] Edmonton: Hurtig Publishers.

1963: Edmonton Trader: The Story of John A. McDougall. Toronto: McLelland and Stewart.

1981: A History of Alberta. [1972] Edmonton: Hurtig Publishers.

SHEREMATA, JAMES

1970: "A Survey of Professional Entertainment and Theatre in Edmonton, Alberta Before 1914.” M.A. Thesis, University of Alberta.

STORER FAMILY FILE

Alberta Provincial Archives and Museum, Edmonton, Alberta.

The author and editors gratefully acknowledge the permission of the Provincial Archives and Museum of Alberta for the photographs published with this article. 


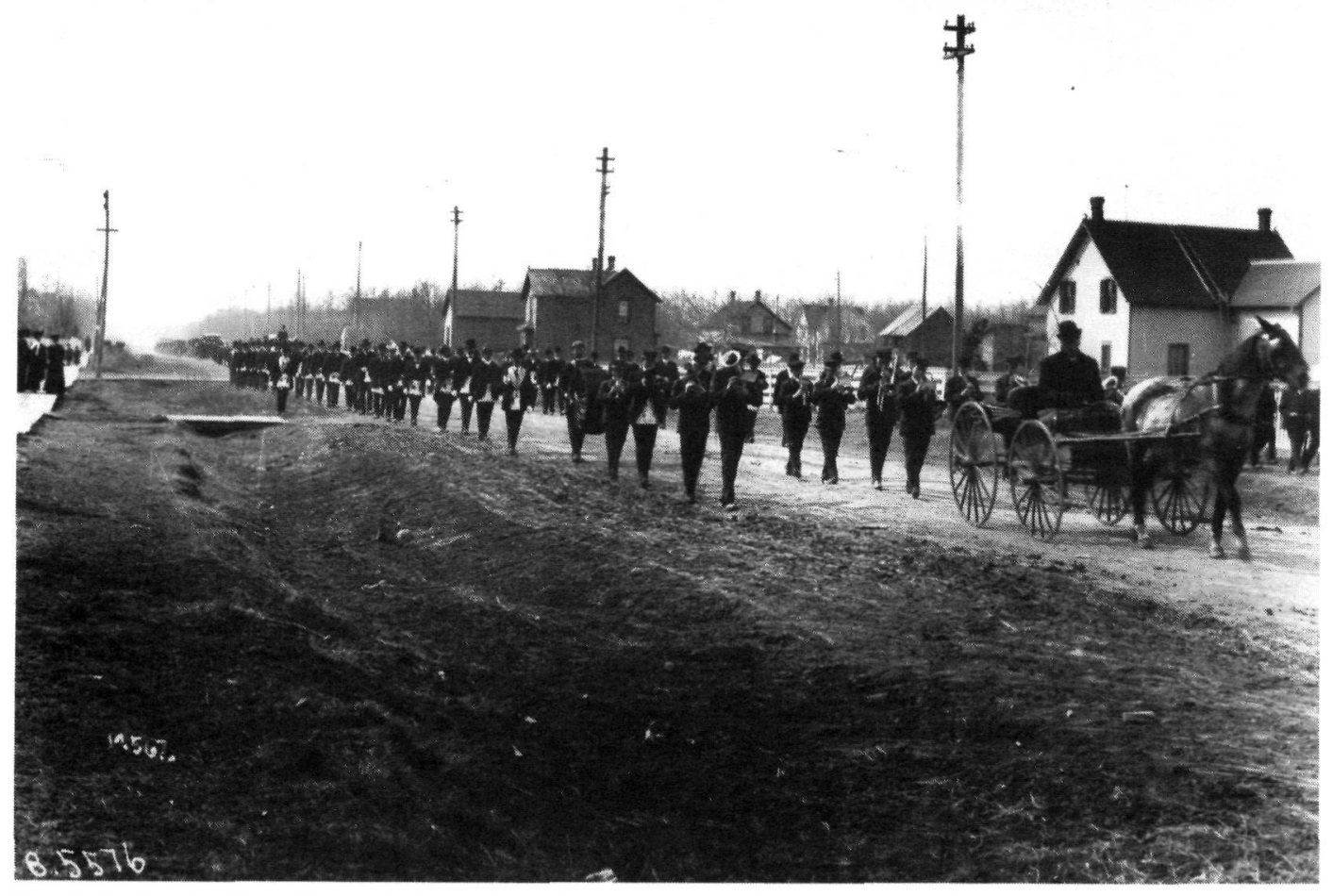

Band playing for Tom Horten's funeral on Jasper Avenue C.1895. Provincial Archives of Alberta: E. Brown Collection B5576 "Reprinted by Permission" 


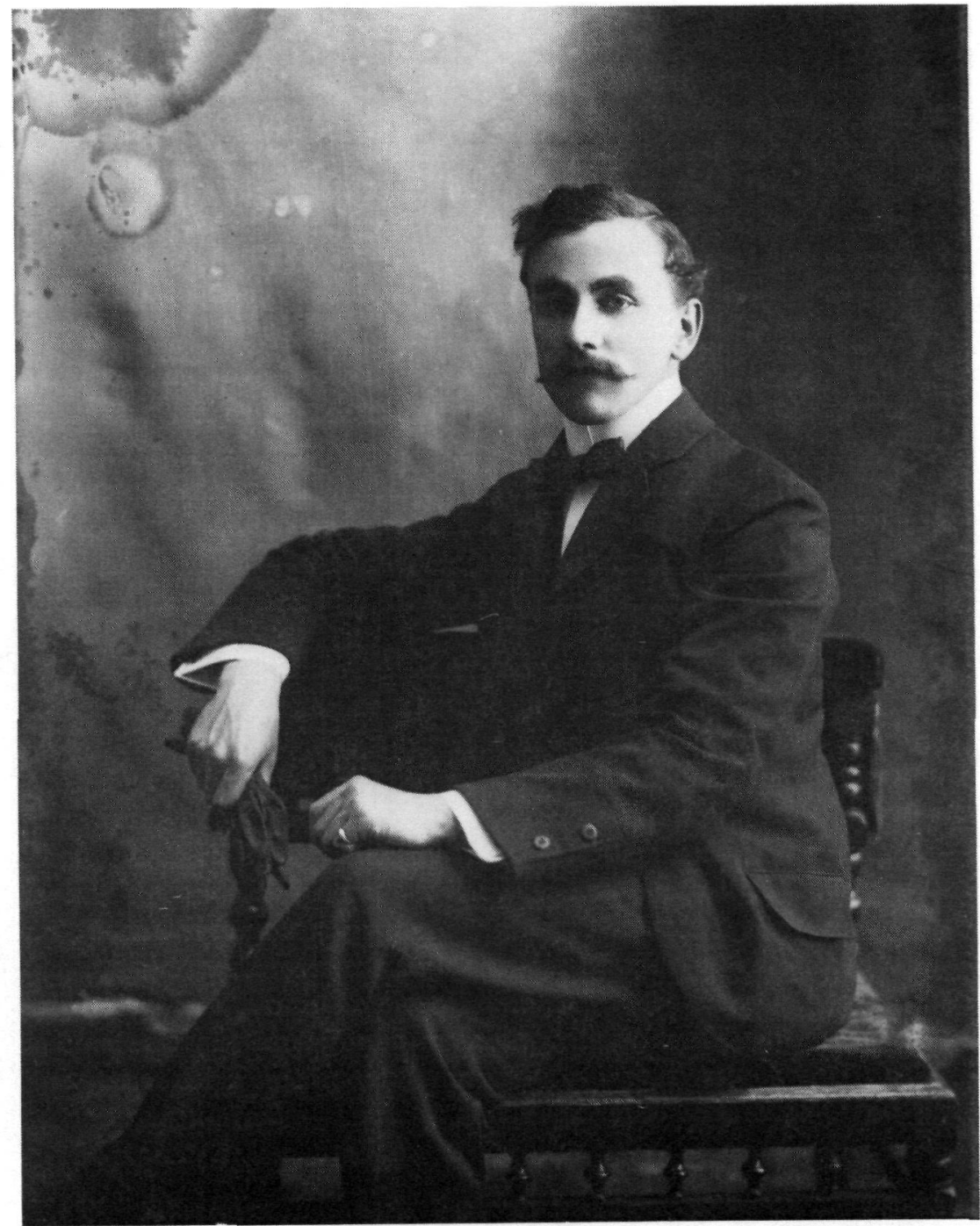

Mr. Vernon Barford. Provincial Archives of Alberta: E. Brown Collection B4178 "Reprinted by Permission" 


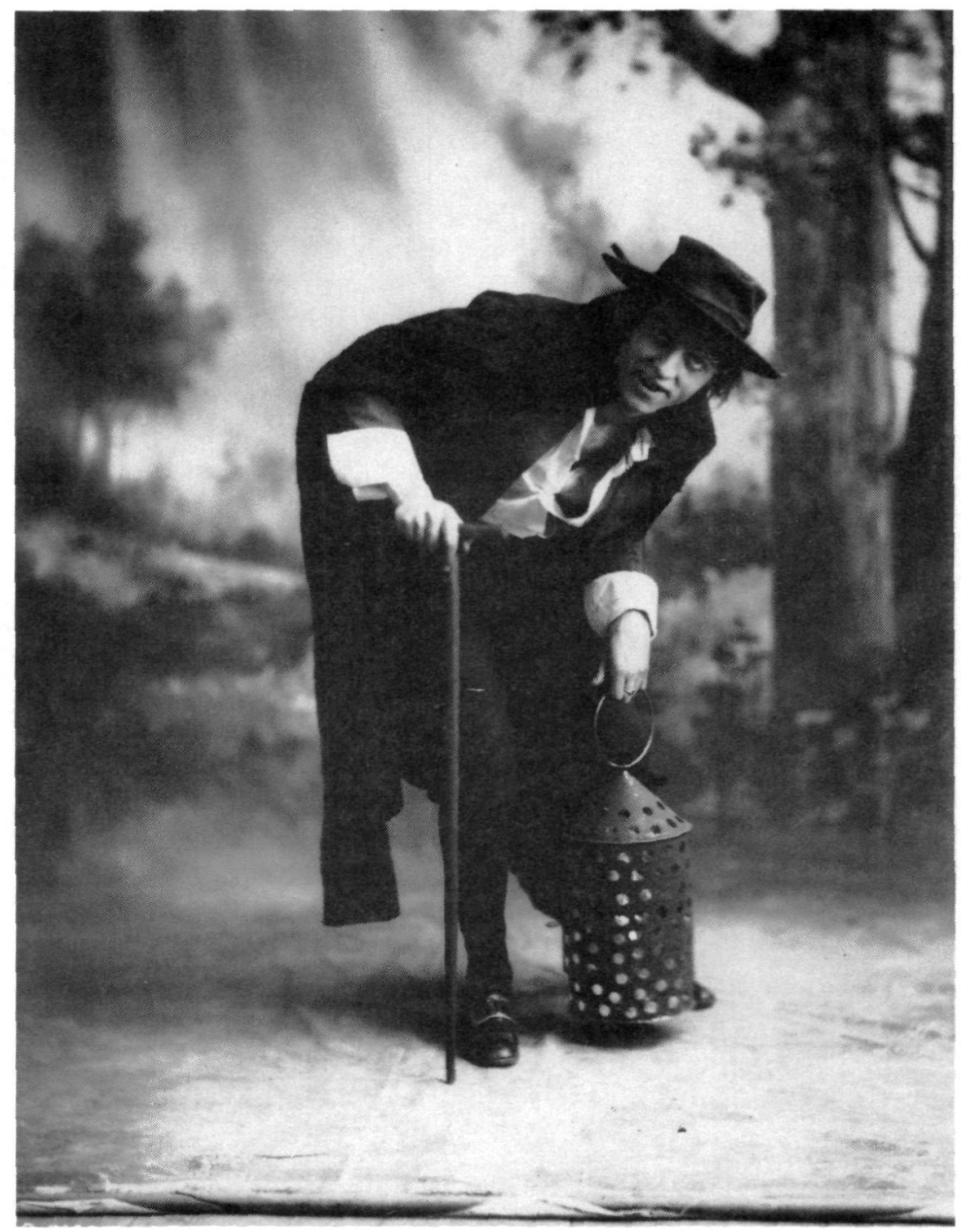

Howard Stutchbury in The Chimes of Normandy, 1904 Provincial Archives of Alberta: E. Brown Collection B9100 "Reprinted by Permission" 


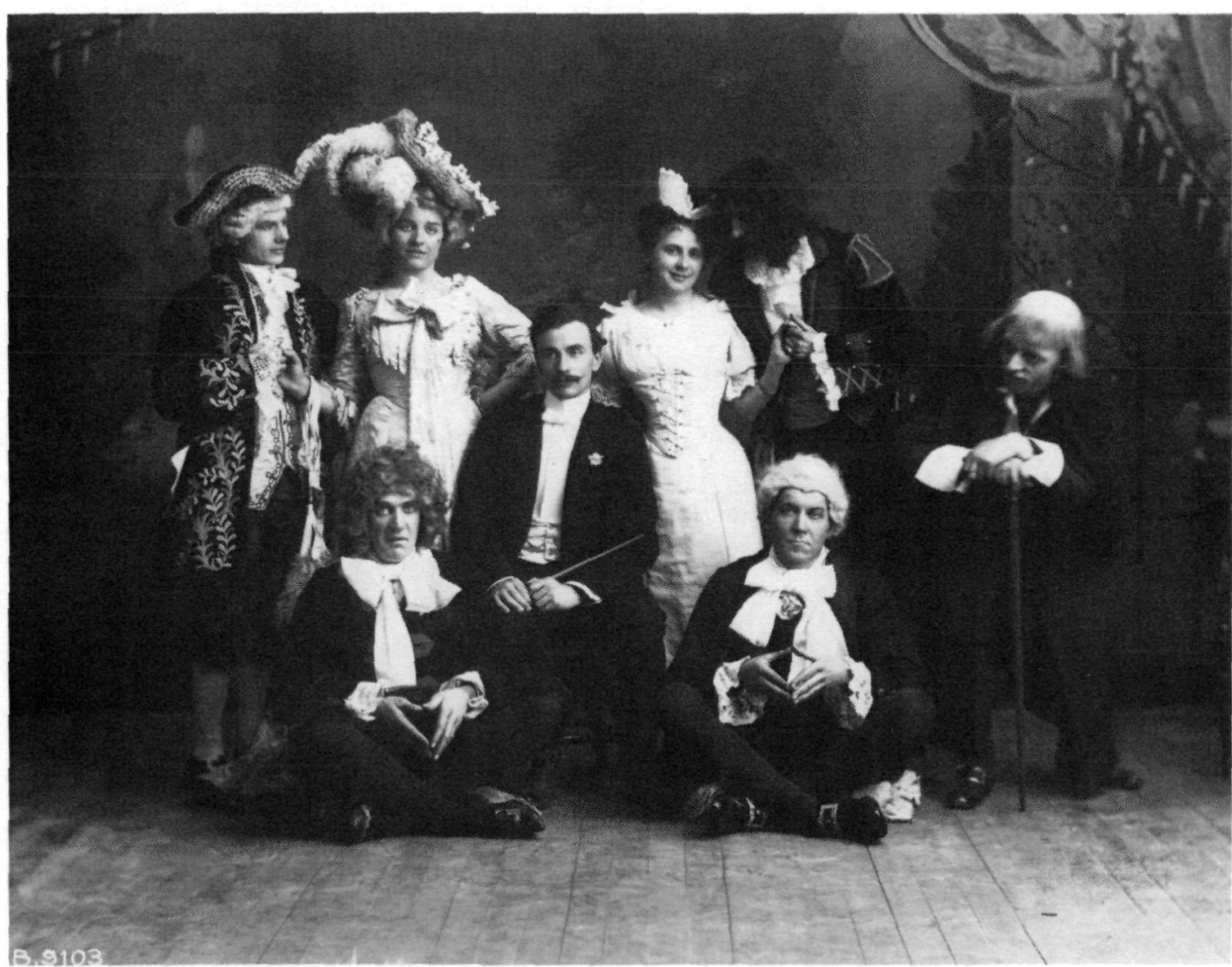

Cast of The Chimes of Normandy in Robertson Hall, 1904 Provincial Archives of Alberta: E. Brown Collection B9103 "Reprinted by Permission" 


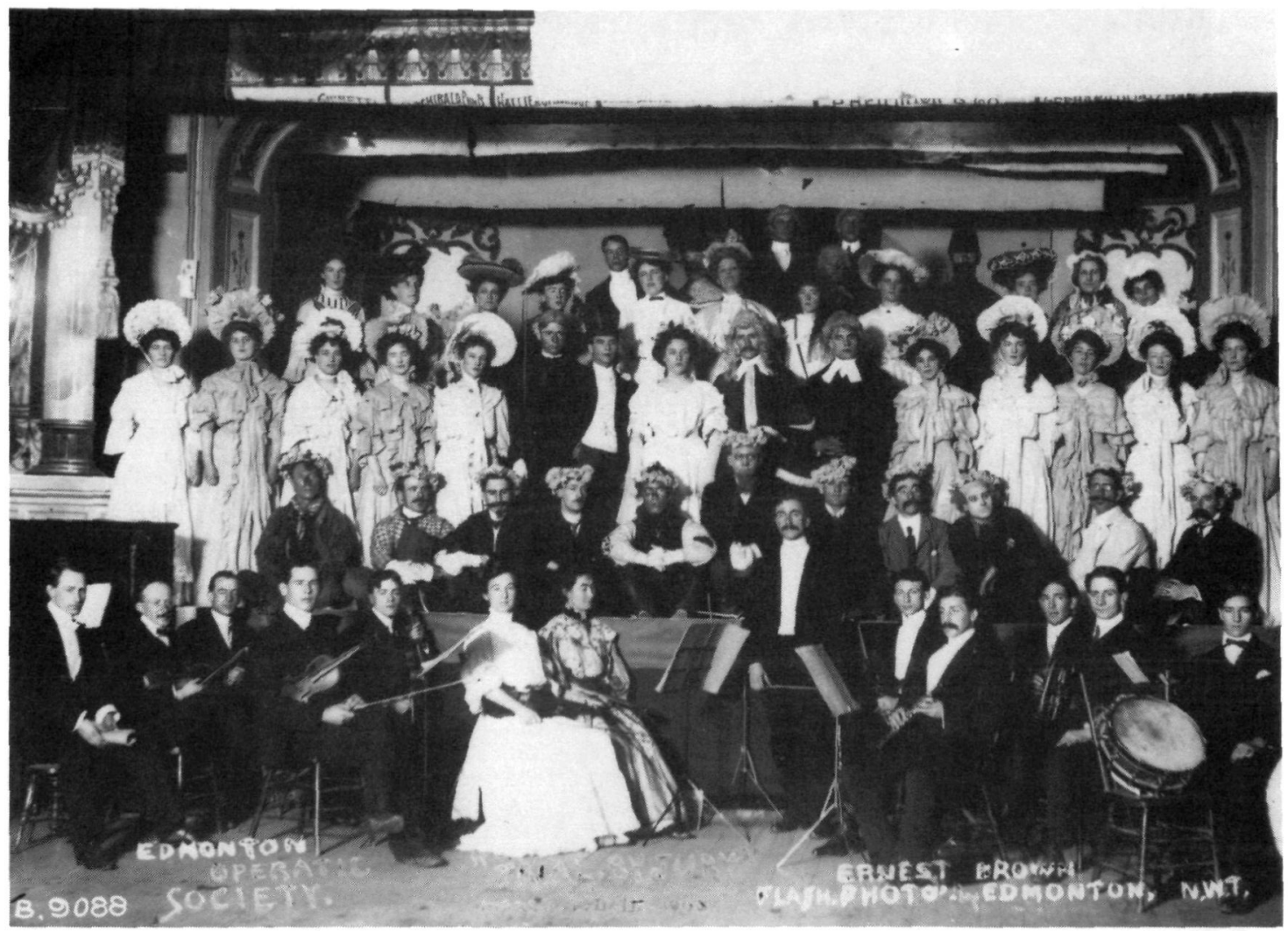

Cast of Trial By Jury in Robertson Hall, 1905 Provincial Archives of Alberta: E. Brown Collection B9088

"Reprinted by Permission" 


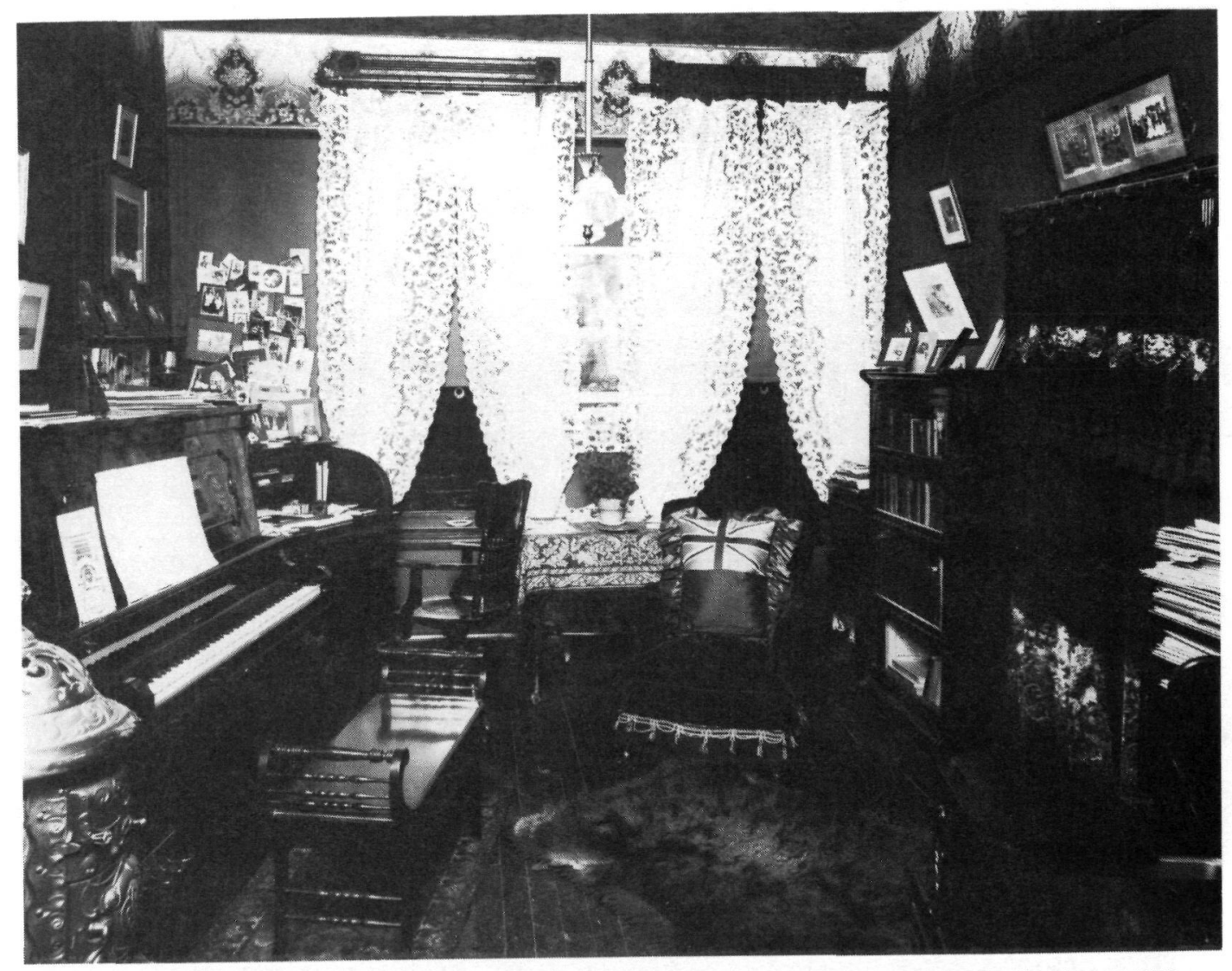

Vernon Barford's music studio in 1902 Provincial Archives of Alberta: E. Brown Collection B4179 "Reprinted by Permission" 